Marija Stefanović, $\mathrm{MA}^{1}$

Independent researcher, Niš, Serbia
Оригинални научни рад

UDK 316.644.82:811.163.41’282.3

Примљено: 15.8.2019.

Ревидирана верзија: 10.10 .2019 .

Одобрено за штампу: 11.10.2019.

DOI: https://doi.org/10.46630/gsoc.22.2019.01

\title{
TYPES OF STRATEGIES OF THE SOUTHERN DIALECT SPEAKERS
}

\begin{abstract}
The paper focuses on the Southern Serbian dialect speaker linguistic strategies in everyday interactions, with emphasis on the academic setting. Building on the findings of the qualitative research (in-depth interviews), a possible classification of the Southern speakers (standardizing, non-standardizing and eclectic group) is proposed. The analysis of these groups and their linguistic strategies (convergence/ assimilation, divergence/dissimilation and maintenance) is conducted in an interdisciplinary manner, interfacing the Bourdieusian theoretical framework with the key concepts from the Communicative Accommodation Theory (CAT). In addition to contributing an authentic approach to studying and understanding language-based stigma, and the power relations underlying it, the goal of this paper is to point out the potent alleys for future research.
\end{abstract}

Key words: Southern dialect, linguistic strategies, stigma

\section{Introductory remarks}

This paper introduces the findings of the empirical research on the Southern Serbian dialect speaker ([future] educators) strategies in their daily interactions. The specific position of the speakers of the stigmatized Southern dialect ${ }^{2}$ will be considered within the Bourdieusian theoretical matrix which assumes that every linguistic exchange displays power relations. In the first part of the paper we will present the key notions and terms we use in the analysis of the Southerners' linguistic strategies. These notions include Bourdieu's concept of the field and the strategies agents use in power struggles as well as the types of strategies (convergence, divergence and maintenance) defined within the Communication Accommodation Theory (CAT). Building on the material collected by way of 25 in-depth interviews, the second part

\footnotetext{
${ }^{1}$ MarijaStefa@hotmail.rs

${ }^{2}$ The associative sequence most often related to the typical Southerner-uneducated, ill-mannered, hilarious, of low cultural taste, poor..., results from the notion of rurality, cultural and economic underdevelopment (backwardness) of the South and Southern Serbia (which is also attributed with such labels as the "periphery" and "southern track") (Petrović 2015: 12). The Southern dialects are also perceived as incorrect and ugly, incomprehensible even, making the overall representation of the speakers of these dialects almost caricature-like (more about the perception of and attitudes toward Southern Serbian dialect: Stanković \& Stefanović 2019; Paunović 2009, 2008; Kovačević 2004, 2005).
} 
of the paper proposes a possible classification of the groups of Southern Serbian dialect(s) speakers who apply the strategies of (upward and downward) convergence and divergence (standardizing, non-standardizing and eclectic group, respectively), with the aim of achieving symbolic profit on certain linguistic markets. Also, we will consider the specific power relations unveiled within and among the groups as well as the way the speaker strategies affect perpetuation of the existing power relations and established hierarchies. In addition, this paper raises a wide variety of questions which are to encourage further investigations and opens up a space for the interdisciplinary dialogue.

\section{Theoretical and methodological framework}

\section{1) Theoretical framework}

The field struggles over the valuable resources are concentrated around the specific forms of capital (economic, cultural and social). The linguistic capital, as a part of the cultural capital, is crucial, for instance, in the intellectual field or in the field of education. In the same way as the economic capital is crucial in the field of business. The agents in the field do not just fight over the resources, but also over the definition of what is valuable in a certain field. In that sense, fields are battle arenas for legitimacy, i.e. for the monopoly over symbolic violence (Bourdieu 1977a, 1991). According to Bourdieu, struggles in the fields are fought between the dominant and the dominated, i.e. between those who already possess a monopoly on the definition and the distribution of the capital ("the established agents") and those who want to usurp that advantage ("the newcomers"). On the other hand, the struggles fought in the field are aligned along the orthodoxy-heterodoxy line, namely, between those who want to preserve the $\operatorname{doxa}^{3}$ and those who want to change it (Bourdieu 1991; Bourdieu \& Passeron 1977).

Bourdieu and Wacquant compare the struggles in the field to the game in which the power relations between the players define the structure of the field: each player has tokens of various colors (capitals) and the position of each player in the game as well as their strategic orientation depend on the amount and the composition of the tokens they possess (i.e. the scope and the structure of the capitals they have access to). The agents, for example, can conform to the rules of the game in order to improve or preserve their capital; on the other hand, their strategies can be oriented toward changing the rules of the game or discrediting the form of capital which gives their opponent the power (Bourdieu and Wacquant 1992: 99).

In order to emphasize the difference between the everyday practices and their formalized models, Bourdieu introduces the notion of strategies as the substitute for the notion of a rule. The strategy concept, as Swartz explains (1997: 99), implies that every action taken by agents consists of particular uncertainty. Even the behaviors

\footnotetext{
${ }^{3}$ The experience by which "the natural and social world appears as self-evident" (Bourdieu 1977a: 164); a society's taken-for-granted, i.e. common beliefs.
} 
that become a routine require strategies to a certain extent. However, strategies applied by the agents are neither a product of the moment nor the matter of conscious choosing or rational calculation. They are rather determined by the practical dispositions (habitus) which evolve over time. In that sense, the agents are "strategic improvisers who respond dispositionally to the opportunities and constrains offered by various situations" (ibid.: 100).

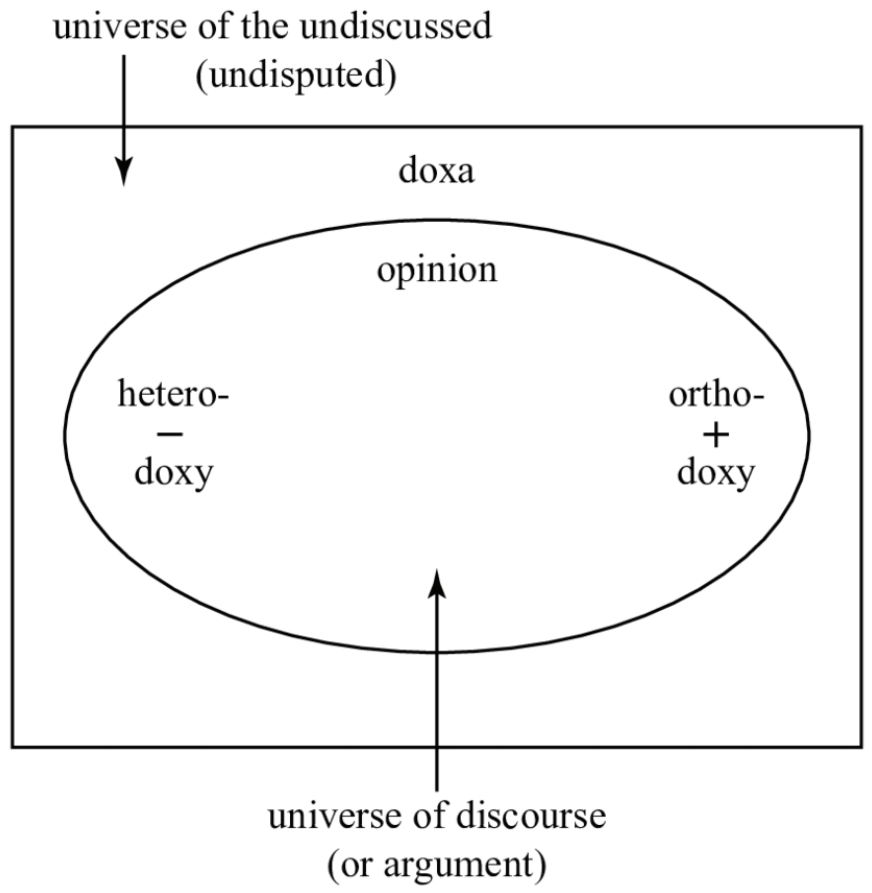

Figure 1: The relation between the different strategies (Bourdieu 1977a: 168)

Bourdieu (1993) differentiates between three types of strategies: strategies of conservation, succession and subversion. Strategies of conservation are employed by those occupying the dominant positions which they want to preserve or improve in the field, i.e. to protect the distribution and valuation of the capital to the best of their interest. Strategies of succession are applied by the newcomers to the field, those who endeavor to gain access to the dominant positions (or at least to be recognized as legitimate agents in the power struggles). The dominated agents apply subversive strategies in order to change the existing principal of the capital valuation or to change the rules of the game in the field ${ }^{4}$. All the strategies are oriented toward the

\footnotetext{
${ }^{4}$ As an illustration of the strategies that can be adopted during field struggles, Bourdieu describes the different usage of language by the social classes (e.g. the strategy of hypercorrection is characteristic for the members of petty bourgeoisie, whilst the strategy of hypo-correction or condescension is used by members of the higher classes etc.).
} 
recognition or negation of a distinction (assimilation and dissimilation strategies).

The illusion or the belief that playing the game is as worthwhile as is investing in it enables the game to be reproduced. The paradox of the field uncovered here is that although some strategies have a tendency to change or invalidate the field's structure the effect is exactly the opposite - they enable and encourage the reproduction of the existing structure of the field (Bourdieu 1991: 64).

The Communication Accommodation Theory - CAT (Giles 1980, 2016; Gasiorek \& Giles 2012; Giles \& Ogay 2007; Shepard, Giles, \& Le Poire 2001; Giles \& Powesland 1997) suggests a similar typology of strategies. Strategies of convergence are linguistic strategies applied by the speakers who have the tendency to adapt their linguistic behavior (their accent, lexicon etc.) to that of their interlocutor, in terms of similarity. Divergence is a reversed process that implies the speaker's tendency to adapt the behavior so as to be different from that of the interlocutor. The maintenance strategy refers to the tendency to maintain the existing level of communication without any adjustment. In the case when the dimension of the adjustment has a certain social value - as is the case with dialects and other non-standard forms of talk - it can be conceptualized as an upward (adjustment to more prestigious variety) or downward adjustment (adjustment to less prestigious or stigmatized variety) (Giles \& Powesland 1997). Therefore, when the speaker of a non-standard language adjusts his/her language to the standard language we have an example of an upward convergence; when the standard language speaker tends to adjust to a non-standard language of her/his interlocutor it is an example of a downward convergence. Emphasizing one's own non-standard dialect or accent in interaction with a standard language speaker reflects downward divergence, whereas adopting a standard language in interaction with a non-standard speaker is the case of an upward divergence (Dragojević, Gasiorek \& Giles 2016: 37).

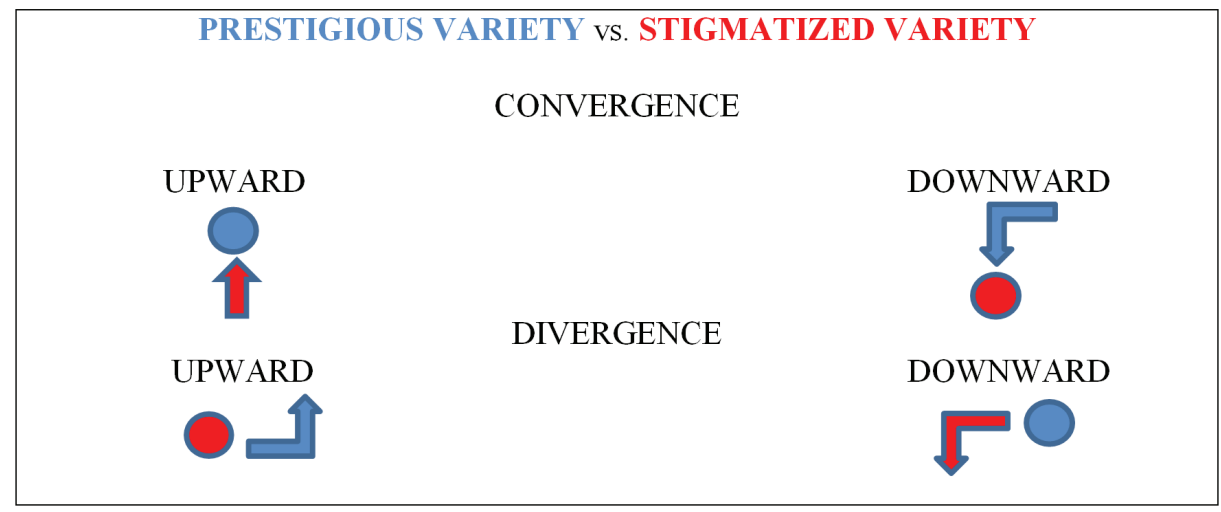

Figure 2: Accommodation strategies in linguistic interactions

\section{2) Methodological framework}

The qualitative research that took place at the Faculty of Philosophy in Niš, during the period of June 2016 to March 2017, involved the acquisition of data 
by means of the semi-structured in-depth interview. The interviews (25) were conducted with the university professors and students (23 of them are Southerndialect natives, 2 of them are from the west part of Serbia). Conversations with the informants have been conducted based on five (introduction excluded) determined thematic units, which the interviewer then navigated (on a need basis) with questions and sub-questions. Prior to the interview, the participants had been asked to provide the basic socio-demographic data: age, place of birth, current residence, level of education, parents' level of education. The snowball/chain sampling was used. All the interviews were recorded with participants' permission, then transcribed and, along with the researcher's notes, used as material. The researcher's notes included observations and comments on the content of the informants' statements, e.g. ambiguous attitudes, contradictions etc. Additionally, what was also recorded was the informants' speech (i.e. whether their speech is closer to the standard/dialect variety or not, whether they tend to make hypercorrections, or they switch language codes etc.) as well as their facial expressions and gestures. Identification and the classification of the speaker groups resulted both from the researcher's observations of the interviewed speakers' language practices and the participants' narratives, i.e. their attitudes toward the language practices of the people from their surroundings.

\section{Strategy types of the Southern Serbian dialect speaker}

This section considers the qualitative research findings, first, in terms of the factors that affect speakers' strategic orientation in everyday interactions and, second, in terms of the Southern Serbian dialects speakers' types of strategies (i.e. when, how, why and what strategies they apply).

Considering that our research interviews have been conducted with the university professors and students, we noticed that their perception of the different language varieties is mostly determined by the identification with both the professional (the educators) and the geographical (the Southerners) group. The participants' perception and the attitudes are modified in accordance to the 'stronger identity', i.e. the group they identify more with. Also, the attitudes toward certain language varieties are underpinned by the stereotypes of personal identity, which imply the assessment of one's abilities, intelligence, self-confidence, aspirations etc. Taking into account all the above mentioned, we can distinguish between the following factors that affect language strategies and tactics:

- Who the speaker is? (the identity issue): whether the speaker's linguistic practices are conditioned by the identification with a certain group (professional, geographical, socioeconomic, educational...), or by the issues concerning personal identity;

- Who the interlocutor is? - whether the interlocutor is a Southerner or not, educated or not, a family member, a student, a professor...;

- Where is the linguistic exchange taking place? - e.g. Southern or nonSouthern region, at the faculty or not etc.; 
- On what occasion? - formal/informal context;

- Anticipation (symbolic profit) - the speaker anticipation of what can be gained through linguistic interaction.

In accordance with their "stakes" (linguistic capitals and habitual dispositions) and with regard to the listed factors and circumstances, speakers apply strategies of assimilation/convergence, dissimilation/divergence or strategies of maintenance.

Based on their linguistic practices, we recognized three groups among the research participants:

1) Standardizing - speakers who always speak standard language (or a variety that is closer to the standard than to the dialect forms);

2) Non-standardizing - speakers who always speak in a Southern dialect (or in a variety that is closer to the dialect);

3) Eclectic - speakers who switch codes and language varieties (from the local to the substandard and standard) in accordance with their own assessment.

Within each group, the agents apply different strategies (sometimes they simultaneously apply more than one strategy), thus, among them various subgroups can be distinguished.

In the following section we will briefly describe the most significant characteristics of each group including the motives of the strategic orientation, subjective and objective constrains (speakers' capacity to produce adequate linguistic products for different markets; sociocultural norms), and the strategies' outcomes. Also, we will consider the specific power relations that can be unveiled within and among the groups as well as the way the speaker strategies affect the perpetuation of the existing power relations and the established hierarchies.

\section{1) Standardizing group}

This group consists of speakers from Southern Serbia who always (try to) speak standard Serbian language regardless of the circumstances (who the interlocutor is, where the linguistic exchange is taking place, whether it is a formal or informal context etc.).

The knowledge and the usage of the standard variety is perceived as prestige and as a sign of those who are educated or hold higher positions within the social hierarchies. In this sense, language is the means to a distinction. By using the prestigious language variety, speakers claim their dominance over the "typical Southerners" who are assumed to hold lower positions within different hierarchies. Likewise, linguistic behavior and strategies employed by this group are par excellence proof of the existence of both stigmatization and auto-stigmatization of the Southern dialects.

Participant 22: I always try to speak the standard language... always trying to avoid my dialect, to uproot it. (...) When I'm here, in Niš, I also try not to speak in the dialect. (...) (I: Do you like your dialect?) No, not at all. (I: Why?) Because it does not sound similar to the standard language. I would like it to sound more... more 
similar to the standard. (I: Why?) Well, I can say that I really mean that... You know why those from the north sound prettier to me? They follow the standard language rules, that's why. They do not make grammatical case errors and some words sound prettier when they are pronounced differently. (...) (I: What do you think would there be any consequences, if you dared to speak in your own dialect?) Yes. (I: What consequences are we talking about?) I think that people would think I know less. (...) I have the impression that everyone can hear and notice my dialect, do you see? (I: Can you elaborate on that? What would that person think of you if s/he hears you speak that way?) ... That I don't know how to speak, let alone something else... (I: You think you would sound bad no matter what the quality of the content of your speech was?) Yes, for sure. I have to try harder, the same way the people who live more to the south of Niš have to try harder to be considered equal. You know, people from Vranje, for example, have to speak in Niš dialect, at least, in order to be on equal footing with us coming from Niš. (I: In what sense do you mean ,on equal footing"?) You know... if you want people to treat you... I don't know how to explain it... if you want to have the same onset position, without prejudices.

Depending on where, when and with whom they speak, speakers of the standardizing group employ upward convergence, i.e. upward divergence. When speaking with the non-Southerners (whose language is closer to the standard variety) they use the upward convergence. When speaking with those in a higher or authoritative position (regardless of their geographical origin) they also tend to use the strategy of upward convergence. When interaction involves a speaker of the nonprestigious or stigmatized language variety, i.e. interaction with the Southern dialect speaker or with someone who holds a lower position within a certain hierarchy, this group uses the strategy of upward divergence. The motive for such strategic orientation may be to create or maintain a positive personal or social identity, i.e. the signaling (through the usage of a language code) that they do not/belong to a certain group or do not/have certain features or competencies to gain the desired symbolic profit (Bourdieu 1991), or to ensure a potential social reward (Tajfel \& Turner 1986). Paradoxically, even though the standardizing group of speakers consists of the stigmatized Southern speakers, we discover a tendency toward maintaining the existing power relations, dominated by the belief that all non-standard varieties are "incorrect" and "inadmissible" even in non-formal, private communication (speakers' ambivalent feelings about their own language variety were also observed in Paunović's research [2008]). The existing language hierarchy is perceived as a feature of the modern and civilized societies, so questioning the prestigious status of the standard language is seen as a part of the retraditionalization process of the Serbian society and as a symptom of the cultural and economic degradation (Miloradović 2014: 16). As one of the participants explains:

Participant 23: I remember our Serbian language teacher... she was considered a real lady. That was a time when all the teachers spoke the standard language. Now, I think, with this retraditionalization, with all those wars and everything... with regression in cultural development... it seems that suddenly the status of our standard language is being questioned, even though that was never an issue. 
Linking the dialect to the notion of tradition is the discourse which has arisen together with the process of modernization, i.e. with the process of establishing the modern nations and the emergence of the modern elite (the period of romanticism) with the past being idealized (Petrovic 2015: 29). Also, we can notice that the dialect is localized in the past, along with the fact that the notion of contemporary is perceived as the return of the pre-modernity (ibid.). The "Fear" of pre-modernity as well as nostalgia for modernity (which this participant associates with the period of socialism) is projected onto the language which becomes a symbol of backwardness (the Southern dialects) or progressiveness (the standard language) of the Serbian society. It seems that the problem of language for this group is also a matter of survival of the (idealized) identity, both collective and personal. Therefore, by using the standard language they reaffirm that they belong to the "high-brow" milieu.

Some of the research participants belonging to this group stated that they use the standard language variety due to pragmatic reasons, due to its "omnipresence" ("it's everywhere, everybody can learn it" and "everyone will understand me"). The ambivalent nature of the codified standard language is discovered here: unification, promoted as the means against misunderstanding due to the large differences between the language varieties, actually encourages the segregation since it produces, reproduces and intensifies those differences. Such dialectics is a symbolic violence mechanism par excellence (Bourdieu 1991: 140). The so-called standard language cultures (Milroy \& Milroy 1999; Milroy 2001, 2007) are guided by the myth that the standard language is not arbitrary - chosen by the groups and individuals, but that it has its privileged status 'by nature'. This myth, paradoxically, confirms the legitimacy of the standard language, thereby perpetuating the language hierarchy. Although these speakers try to act like the dominant, by using the prestigious language code that does not mean that they always have the pass to the privileged circle. Due to being uncertain because of the lack of standard language knowledge, some of them may have a tendency for hyper-correction (over-correcting the less prestigious "incorrect" variety; Janda 1978) and hypercorrective (incorrect) usage of the prestigious variety (Trudgill 2003: 59-60). A quantitative research on hypercorrections in the Prizren-Timok dialect speaking students (Novaković 2016) has shown that they feel more uncertain than their peers coming from other dialect zones. Also, this study suggests that "the occurrence of hypercorrection in students appears specifically in those situations in which they find themselves face to face with those in a superior position, i.e. the Serbian language teachers" (ibid.: 339). Even though this group employs the upward convergence to make or maintain the positive image, the subjective constraints give a completely opposite effect. However, even when they do not make hyper-corrections, these speakers encounter other objective constraints. For instance, when the Southern dialect speaker from Niš uses standard language in a formal situation to follow up with the sociocultural norms, he or she may face the following reaction of the non-Southern interlocutor: "You speak very well for someone who comes from Niš!". Even though the rules of the game have been followed, the outcome can still be unfavourable: by way of a euphemism the Southerner has been shown his/her place. 
Participant 14: They consider... I mean "they"... The majority I meet often say to me - of course I speak with them in the standard language - they say to me: "We could never guess you are coming from the south!" I say, "Well, you see, not all the people from the south disregard the cases". They literary make fun of it. I'm not sure why that is (...) I suppose they associate it with poor education... (They think) we are uncivilized; that we are peasants running after chickens and pigs all day long.

Also, a total speaker convergence can sometimes be perceived as a patronizing act and the speakers using this strategy can even be perceived as distrustful (e.g. see similar findings: Giles and Smith 1979; Coupland 1988). On the other hand, the group of speakers with the tendency to speak in the standard variety even in nonformal interactions with the Southerners can be labeled disloyal to the group or too arrogant (especially if they correct their accent). Hence, this group somehow finds itself in 'double trouble', as one of the research participants has defined it.

Participant 23:...And on the south there is a case of stigma toward the standard language. You know, the one who speaks the standard language is perceived as arrogant. (...) The standard language is a sort of a skill, and since the majority lacks this skill they tend to reject it. You know like: "don't clown around, say it in proper (down-to-earth) Serbian". (...) That is the rejection and it happens everywhere. And we, we are in a "double-trouble" here.

\section{2) Non-standardizing group}

This group is comprised of those speakers who use the dialect or the variant closer to the dialect in all of the situations and with any interlocutor. Their strategic orientation in interaction with the prestigious variety speaker is, in principle, subversive because it violates the doxa. What characterizes them is the use of the downward divergence, i.e. the emphasis of their own stigmatized dialect or accent.

Given the heterogeneous nature of this group, we have grouped these speakers in two subgroups: a) "ignorant" and b) subversive.

\section{a) "Ignorant" subgroup}

Belonging to this group are speakers who are not able, due to the lack of linguistic competencies (knowledge of prestigious variety), to "deliver" the linguistic products for specific markets. These speakers do not have at their disposal a wide variety of strategies and tactics. They can either speak in their dialect, or choose to remain silent (due to being ashamed).

It was, somewhat, expected for the informants ${ }^{5}$, especially those who completely internalize the dominant standard-language ideology and hierarchy, to ascribe this linguistic practice to the less educated people, those coming from the rural environment or to those coming from the lower socioeconomic classes.

Participant 8: Those are the people who do jobs which bear no public importance. Craftsmen for instance...

Participant 9: When someone does not to speak the standard language, his problem is not the lack of language knowledge, but the lack of education.

\footnotetext{
${ }^{5}$ In response to the question if they knew any person who always used a dialect and what is their attitude toward that.
} 
Additionally, their examples included educated people from their surroundings whom we could put in the "ignorant" group because their use of the dialect is not a consequence of attitude, but of inability to reproduce the socially acceptable variant. In this case the use of the dialect is interpreted either as an indicator that they are uneducated and laymen, or as a confirmation of their (previously presupposed) lack of expertise, closed mindedness even, in spite of their level of education. Given that the majority of the participants have declared that anyone with high school education onwards should, at least to an extent, be capable of reproducing the standard speech variety, but also to develop a "sense of context" (specific language code usage), it is evident why the usage of a dialect is interpreted as their personal handicap.

Participant 21: There was a colleague who spoke a very bad, incorrect language and I really had issues with him. I could not take him seriously as a sociologist because of the way he spoke. But, I think, it was a combination of his poor competencies and his poor language. (I: OK, so his language just intensifies your overall impression of his background, you have already estimated before?) Yes, yes, that would be a good definition.

In addition, the speakers from Niš ascribe this linguistic practice exclusively to those who do not originate in Niš, but are the speakers of the Southern dialects (Leskovac, Grdelica, Vranje, Surdulica, Babušnica...). This again confirms the thesis of the so-called Niš standard language which, in the language hierarchy, occupies a higher point with respect to the remaining Southern speech varieties (a hegemonic relation mapped from the wider social arrangement onto the language $\left.{ }^{6}\right)$.

\section{b) Subversive subgroup}

This group is comprised of speakers who possess linguistic capital, the knowledge of the standard language and are, thus, able to "deliver" the linguistic products for the different markets. But they always behave subversively with respect to the doxa and choose downward divergence as their strategy. The subversive group, although similar to the ignorant group in terms of strategic preferences, is in fact, essentially, in opposition to it. What sets them apart is the linguistic capital, including the awareness of the value their own linguistic products have on the specific markets as well as the motif for choosing the strategies: the former are incapable and cannot, whereas the latter do not want to conform.

Participant 14: My friend from Vranje who has finished both his secondary school and the faculty in Belgrade, always speaks in the Southern dialect with everyone. He says he does that on purpose, because the reputation our dialect has. (...) "Even when I text them", he says, "I do it in the dialect". On purpose. Even

\footnotetext{
${ }^{6}$ For a detailed discussion on the potential responses to stigma and the establishment of the hierarchies see Živković (2001). The observed mechanism of hierarchy can be additionally elucidated by the notion of 'nesting orientalism': "The gradation of "orients" that I call "nesting Orientalism" is a pattern of reproduction of the original dichotomy upon which Orientalism is premised. In this pattern, Asia is more "East" or "other" than eastern Europe; within eastern Europe itself this gradation is reproduced with the Balkans perceived as most "eastern"; within the Balkans there are similarly constructed hierarchies. I argue that the terms of definition of such a dichotomous model eventually establish conditions for its own contradiction" (Bakić-Hayden 1995: 918).
} 
with the professors. (...) Yes, he wants to present himself and acknowledge himself as Vranjanac wherever he goes.

However, the subversive group itself is also heterogeneous in terms of the motivation for such a strategic orientation.

The part of the speakers belonging to this subgroup is aware of the hierarchy and the mechanisms which perpetuate it and they, therefore, choose to use the stigmatized variety (dialect) even in those situations in which this is not suitable, i.e. when it is not in accordance with the sociocultural norms. The downward divergence is a sort of a radical manner for the affirmation and the promotion of their language usage attitude, a way to fight against the negative labeling of their own speech or that of anyone else. A social psychology study addressing the strategies of the speakers of a stigmatized Welsh dialect (Giles and Johnson 1987) confirms that those speakers who are more attached to a specific group or identify with the group (a regional group in this case), have a greater tendency towards using divergence. Divergence observed in the case of our subversive Southern dialects speakers not originating in Niš, occurs in those group members who feel their status to be either illegitimate or unjust within the inter-group hierarchy (Dragojević, Gasiorek \& Giles 2016: 45).

However, such a strategic preference fits within the idealistic approach that Bourdieu (1991) terms "linguistic communism" or Mey (1985) "linguistic democracy", not existing in reality. The reason for this is paradoxical: the question of language is, in fact, not a linguistic question at all. In this sense, the speakers who subversively approach the question of language use, in fact, do not wish, either as individuals or a group, to be discriminated on other grounds that are not linguistic in any way. Following such a logic, these speakers choose as their weapon for the battle, fought in the field of economy, politics and ideology, language which puts them in an ungrateful position per se, opening the space to skepticism in terms of the outcome, but also in terms of the meaningfulness of their struggle.

Certain informants define the use of the dialect in formal situations as an act of bravery, which only reaffirms the presence of auto-stigma among the speakers of the Southern dialects themselves, but also the tension that results from the dichotomy legitimate-illegitimate speech.

There are also those who make use of the downward divergence because they favor their own dialect, i.e. they wish, in every situation, to bring to the foreground the identification with the regional group (Southerners in contrast with those from Belgrade, those from Vranje in contrast to those from Niš). In this sense, divergence becomes a symbolic tactics for the maintaining of the personal identity and cultural specificity (Chapman, Smith and Foot [1977] come to a similar finding in their investigation of the speech strategies of the Welsh). In comparison to those who wish to change the linguistic hierarchy in such a way that none of the dialects is favored over others, for all to be used equally, this part of subversive group even considers their language to be "better", "prettier", therefore, resorting to the overuse of their dialect or accent.

In a research addressing the speech of the youth in Paracin, Leskovac and Vranje, Sofija Miloradović (2014: 146) also observes the dialect to be used as a 
contemporary communicative strategy as well as an identification practice. Aside from Miloradović pointing out that the emphasized use of the dialect is employed as a sort of a linguistic exhibitionism, what also attracts one's attention is her observation that this tendency to intensify the use of the dialect is a consequence of the sociopolitical changes, i.e. one of the consequences of Yugoslavia's breakup (ibid.: 147).

However, although this "brave" group can, at times, create a positive image, sometimes they are even described as inconsiderate or arrogant. The standardizing group is labeled because it has dared, respecting the norm, to lay a claim to the position that does not belong to it, while the non-standardizing is labeled because it does not wish to respect the norm, which is seen as "natural" and "common sense".

\section{3) Eclectic group}

The most numerous group of speakers, the "eclectic" group, tends to switch codes, i.e. apply a wide range of strategies and tactics in accordance with the abovementioned factors. They try to manipulate both the language codes and symbolic meanings of different language varieties in order to gain certain benefits. This group knows the rules of the game the best, has "le sens pratique", hence it has more room for maneuvering, unlike the standardizing and non-standardizing group. Sometimes they will adjust their linguistic behavior to their interlocutor, sometimes to the nature of the occasion (formal domain or not), sometimes to the language environment in which the language exchange is taking place. In some way, they profit from the existing conflicts on the language market by turning the game to their advantage.

Some of them confirm they use the upward convergence in several situations: formal context (e.g. in the classroom), in interaction with people from Belgrade or Novi Sad, with someone who is in the position of authority as well as when the linguistic exchange is taking place in Belgrade or somewhere more to the North of Niš. Although, when the linguistic exchange with the non-Southerner is happening somewhere in the south, on their own terrain, some of them apply the downward divergence. One of the motives for such a strategy, as one of the participants explains, can be to test the benevolence (absence of prejudice) of the interlocutor, especially if $\mathrm{s} /$ he is from Belgrade - the crux of power, and if $\mathrm{s} / \mathrm{he}$ holds an authoritative position.

Participant 9: When choosing language code, we take care of, we calibrate it with respect to the occasion. And most of the time we know how to choose the proper thing with regards to the interlocutor and the "stake" at hand. Therefore, when interacting with someone from a different speech community sometimes we speak in a dialect for the sake of appeal and, sometimes, we rather choose the standard in order to "profit"...

Participant 14 (talking about the interaction with his professors): So, the way they speak, I always do my best that my speech matches theirs. So, the adjusting again. My grade is in their hands... Actually, everyday situations included, if I hear someone speak the standard language I go for it too. And if the person speaks in a dialect, again, I do the same.

Also, some of them stated that when in Belgrade they would rather use the downward divergence as a sign of loyalty to their own regional group. The statements 
of these speakers confirm the standard language not to always be a prestigious variety, especially in Vranje and Leskovac. Similar conclusion is presented by Miloradović in her study on the language of youth in Paraćin, Leskovac and Vranje (Miloradović 2014). Furthermore, our research confirms Miloradović's observation that the vernacular of Leskovac and Vranje is being even more stigmatized by the speakers from Niš because they preserve the dialectical foundation of the surrounding villages (ibid.: 145).

However, even though the majority of these speakers stated they would use the standard variety in a formal situation, we noticed absence of consensus on what situation exactly is seen as formal ${ }^{7}$. But their perception, same as their strategies, is of course not arbitrary. It is rather determined by their habitus and the cultural capital they possess. Pursuant to this, if someone has the knowledge of the standard language (the linguistic component of the linguistic capital) that does not necessarily mean s/he will achieve success on the language markets, i.e. that does not mean the speaker would be able to use his/her knowledge adequately (the social component of the linguistic capital).

This group of speakers can also resort to hyper-corrections or come to "codeconfusing" situations, as stated by many of our participants. In order to avoid possible embarrassing code-confusing moments, we have noticed that some of the informants use a tactics we symbolically titled "the middle way". Namely, they choose the lexicon which does not demand total adjustment to the accent of the prestigious variety. The upward moderate convergence enables them to show their linguistic competences without coming into conflict with their Southern identity. These speakers actually want to create the new image of "a serious, educated Southerner".

The usage of downward convergence is also common within this group. They usually use it in situations when they want to "untense" the interaction, to make it more intimate and pleasant, especially if it is a formal situation. We have noticed that this strategy is mainly used by the university professors when they want (studentwise) to give an impression of a less reserved, approachable authority.

\section{Concluding remarks and recommendations for future research}

The findings of our analysis that the Southern dialect can sometimes also be seen as the prestigious language do not really fit well with the assumptions commonly held by the scholars (that the prestigious pedestal is usually reserved for the standard variety alone), in particular with those held by the quantitative sociolinguists (Milroy 2001: 532). On the other hand, our findings converge with Paunović's findings

\footnotetext{
${ }^{7}$ One informant from Leskovac suggests that the formal situation is every "business" situation and every interaction held outside the city of Leskovac; the other participant from Niš suggests that the formal situation is every linguistic situation outside the family or closest friends circle, and that is every interaction in any public space (public transport, taxi, post office etc.). Unlike our participants, the participants in Paunović's research were able to make clear distinction between more and less formal situations ,,in which speech is 'standardized'“ (Paunović 2008: 12).
} 
that suggest participants' overall attitudes to (Serbian) standard speech are not straightforwardly positive (Paunović 2008: 7). In addition to the explanation provided by Goffman (personal "code of honor"), i.e. Živković (2001) who observes that one of the responses to stigma is also an attempt to change the negative belief by means of declaring personal superiority, such an assumption could also be substantiated with Labov's (1972) concepts of overt prestige and covert prestige introduced with the aim to explain the correlation between the social stratification and language ${ }^{8}$. Given that they perceive themselves to be the members of the groups with a higher status (professional group identification), our standardizing group, but also a part of the eclectic group, supports the national norm of power distribution and maintaining. The non-standardizing group (the subversive subgroup, in particular) and partly the eclectic group advocate the covert prestige, thereby demonstrating their membership and loyalty to the regional group. Our research shows that this very power relation is not being revealed only in the standard-non-standard speech relation, but the game between the overt and the covert prestige is also revealed in the inter-group relations between the Southerners. In the established hierarchy the Niš substandard variety occupies the highest position with respect to other, less prestigious, Southern varieties (Leskovac, Vranje, Pirot etc.). Thus, the covert prestige of those less prestigious varieties is revealed in the strategies of the, so-called, Niš non-natives employed in the interaction with those native to Niš. In spite of this, in the background of this symbolic hierarchy we still reveal the standard-non-standard distinction, which is the criterion for the establishment of the Niš-non-Niš dialect hierarchy. Here we reveal multiple "struggles": the symbolic struggle of speech more proximal to the standard and that which is more distal from the standard; the dominance of the city that is economically and politically more powerful (because it is larger and closer to the crux of power - Belgrade) in comparison to the cities which find themselves at lower positions in the hierarchy; the struggle between the orthodox (established agents), Niš-natives, and the heterodox, Niš-newcomers (non-natives), who wish to usurp "Niš domination".

In fact, the relation Belgrade-South (center-periphery) is being reflected onto the relation Niš-other cities in the South of Serbia, and going as far as the smaller units: city-village.

On the other hand, we notice that in the academic setting ${ }^{9}$ the identification with the professional group (except for/in the non-standardizing group) is dominant. When speaking from the position of an educator (or an educator-to-be), the speaker supports the overt prestige (upward convergence) and adjusts the attitude to the

\footnotetext{
${ }^{8}$ The overt prestige is related to the standard variants and is openly recognized and acknowledged by the higher status groups, but also (most often) by the entire (speech) community, whereas the covert prestige is tacitly ascribed to the non-standard variants by those groups with the lower status. Coupland (1988: 94) observes that this concept is similar to the sociolinguistic concepts of power and solidarity, which suggest that overt prestige originates in the power dimension revealed in language use, while the covert prestige is tied to the notion of solidarity reflecting the social affinities and joint experience.

${ }^{9}$ Communication between the teachers and the students, communication between the colleagues, formal and informal communication at scientific gatherings and other similar events.
} 
national linguistic norm. ${ }^{10}$ Nevertheless, we conclude that, in the academic setting, there are no rules in the evaluation of the specific linguistic behaviours or strategies. Those speakers who employ the downward divergence or the downward convergence are in certain cases positively evaluated (due to the existence of covert prestige), as such behavior is interpreted (by the Southerners and within the Southern speaking region) as a sign of loyalty to the group. Certain research (see e.g. Simard, Taylor \& Giles 1976; Gasiorek \& Giles 2012; Dragojević, M., Gasiorek, J. \& Giles, H. 2016) suggests that those speakers who employ convergence are more favorably evaluated when their linguistic behaviour is ascribed to their good intentions to break the e.g. cultural barriers. However, the speakers who employ divergence are more favorably evaluated in those instances where this strategic choice is ascribed to some sort of external pressure and not to their malevolence ${ }^{11}$.

The strategies of the eclectic group also reaffirm Fishman's thesis of the possibility that the "contemporary individual" possesses capacities for multiple loyalties, identities and group memberships (1977: 33). Gumperz also suggests that social categories we take as parameters and the limits to our social identities are, in fact, not "constants that are to be taken 'for granted', but are produced throughout communication" (1982: 1). In this sense, the eclectic group, by manipulating the language codes, is, in fact, attempting to balance multiple social identities with the aim of making symbolic profit.

Due to the sample size-limitations we are unable to sketch the entire possible correlation schema of the linguistic strategies (i.e. speaker groups) with the sociodemographic characteristics of the speakers. However, based on the insightfulness of the data, we can assume the existence of certain connections. Focusing on the informants coming from Vranje, Leskovac, Grdelica, i.e. locations which are, on the intra-group (Southern[er]) imaginary ladder, at a lower point of the disparagement gradient, two ambivalent tendencies are observed. One, a tendency toward the more subversive strategies, with the identification with the regional group being more pronounced than is the case with the participants from Niš. Two, observed as well is the pronounced tendency toward assimilation/convergence, pointing to the complete internalization of the dominant hierarchies. The symbiosis of the two opposing tendencies in a single group with the similar features indicates that both the response to stigma and the linguistic strategies are more radical (in both directions: the complete acceptance of the dominant hierarchies and convergences, i.e. the complete rejection and the divergent linguistic strategy) in those speakers who are the most stigmatized. That implies these tendencies will be most evident

\footnotetext{
${ }^{10}$ Similar findings, namely, that in the academic setting membership in a professional group affects linguistic behaviour to a greater extent than for example the identification with the ethnic or regional group, have also been arrived at by (Jones, Gallois, Barker and Callan 1994).

${ }^{11}$ We have seen for example that the strategies of the subversive group are often evaluated negatively because such behaviour is experienced as hostile, inappropriate and even arrogant; the standardizing group is, in the same manner, evaluated by the Southern speakers.
} 
in the multiply stigmatized ${ }^{12}$ (e.g. the Southern speakers who come from a village located in a county in the South that is not a part of the county of Niš). Additionally observed is that those residing outside the Prizren-Timok speech zone (e.g. those who have studied at a university in Belgrade or Novi Sad) or those who have had a more extensive experience with the speakers of the standard variety (e.g. scientific conferences, gatherings and interactions alike within the academic or business settings) are more prone to convergence, i.e. code switching (the eclectic group) than to subversive strategies and tactics.

As a final remark, we can suggest certain directions particularly worth investigating further, including all of the previously sketched out hypotheses on the correlation of speaker characteristics and their linguistic behaviour. A possible tendency has been observed that those speakers whose parents were particularly mindful of their speech at the preschool age, or during the first educational cycle, are more prone to internalizing the dominant linguistic hierarchy (in which the standard language equals prestige). But who, also, in accordance with this, have a pronounced negative attitude toward their own dialect, why they can be expected to be more prone to the upward convergence. In relation to this, imposing itself is also the assumption of the correlation between the educational, i.e. parents' cultural capital and the scope of the children's linguistic capital. Our research also saw speakers whose parents have less of an educational capital, who have always used the dialectic variety when speaking with their children and who were not particularly mindful of the(ir) speaking in general, be in discordance with the language practices when starting school (Bourdieu's "cleft habitus"). However, they have increased their linguistic capital through(out) the educational system (in parallel with the internalization of the dominant hierarchy "instilled" by way of the school system, their linguistic strategies leaned more toward the upward convergence). On the other hand, there have also been those speakers whose parents have obtained a primary or secondary school leaving certificate, but who consider their speech not to be more different than the speech of their teachers and other classmates. Then again, we have also encountered those speakers whose parents are highly educated and who possess the linguistic capital ("valuable" on the linguistic market), who have in the course of their education formed specific attitudes toward language which have, further, also determined their specific linguistic strategies - subversive, and a specific relation to stigma. In this sense, we have observed a potential for the "deinternalization" of the dominant hierarchies and ideologies, i.e. for the "resetting" of the attitudes and practices learned at home and in school (conditionally speaking, the "resetting of habitus"). This brings us again to the ambivalent relation of the educational to the linguistic capital: on the one hand, such findings lead us to the assumption that the degree of internalization of the dominant language hierarchy is proportionate to the duration of the studies ${ }^{13}$; on the other hand, the more extensive the educational

\footnotetext{
${ }^{12}$ Stigma of the South in comparison to the rest of Serbia, stigma of the "more southern South" in comparison to Niš, stigma of the village in comparison to the city.

${ }^{13}$ The higher the level of education, the higher the degree of internalization of the dominant hierarchies,
} 
capital of the speaker, the greater the possibility, as a result of "becoming aware" of the relations of power revealed in language, for this hierarchy not to be internalized at all, or better yet to cease to be internalized. The paradox of the educational system itself is that it equally evolves the mechanisms (as a legitimate authority) for the production and the reproduction of the dominant ideologies (standard-language ideology, in particular) and enables the conditions for its own demystification.

As already pointed out earlier, all these assumptions are more to be observed as potential questions to investigate on a larger sample and employing the methods that facilitate the generalization of the findings to the general population.

\section{References}

Bakić-Hayden, M. (1995) "Nesting Orientalism: The case of Former Yugoslavia”, Slavic review 54, No. 4: 917-931.

Bourdieu, P. (1977a) Outline of a theory of practice. Cambridge: University Press.

Bourdieu, P. and Boltanski, L. [1973] (1977) "Changes in Social Structure and Changes in the Demand for Education" in Giner, S. and Scotford-Archer, M. (eds.), Contemporary Europe: Social Structures and Cultural Patterns. London: Routledge and Kegan Paul, 197-227.

Bourdieu, P. (1977b) “The economics of linguistic exchanges", (trans. R. Nice) Social Science Information, XVI, 6: 645-668.

Bourdieu, P. \& Passeron, J-C. (1977/1990) Reproduction in education, society and culture. London: Sage.

Bourdieu, P. (1991) Language and symbolic power. Cambridge: Polity Press.

Bourdieu, P. \& Wacquant, L. (1992) An Invitation to Reflexive Sociology (trans. L. Wacquant). Oxford: Polity Press.

Bourdieu, P. (1993) The Field of Cultural Production. Columbia University Press.

Chapman, A. J., Smith, J. R., \& Foot, H. C. (1977) „Language, humour and intergroup relations" in H. Giles (Ed.), Language, ethnicity and intergroup relations. London: Academic Press.

Coupland, N. (1988) "Dialects in contact", Journal of language and social psychology, $7(2), 152-157$.

Dragojević, M., Gasiorek, J. \& Giles, H. 2016. Accommodative Strategies as Core of the Theory. In Giles, H. (ed.), Communication Accomodation Theory: Negotiating Personal Relationships and Social Identities. Cambridge University Press: 36-59.

Fishman, J. A. (1977) “Language and ethnicity” in Giles, H. (ed.), Language, Ethnicity and Intergroup Relations. London: Academic Press.

Gasiorek, J., \& Giles, H. (2012) "Effects of inferred motive on evaluations of nonaccommodative communication", Human Communication Research, 38: 309331.

especially because the adopted linguistic practices in the course of education "pay off". 
Giles, H. \& Smith, P. M. (1979) “Accommodation theory: optimal levels of convergence” in H. Giles and R. St. Clair (eds.), Language and social psychology. London, Blackwell.

Giles, H. (1980) “Accommodation theory: some new directions" in S. da Silva (ed.) Aspects of linguistic behaviour. York: University of York Press.

Giles, H., \& Johnson, P. (1987) "Ethnolinguistic identity theory: A social psychological approach to language maintenance", International Journal of the Sociology of Language, 68: 69-99.

Giles, H., \& Ogay, T. (2007) "Communication Accommodation Theory” in B. B. Whaley \& W. Samter (Eds.), Explaining communication: Contemporary theories and exemplars (pp. 293-310). Mahwah, NJ: Lawrence Erlbaum.

Giles, H. \& Powesland, P. (1997) "Accommodation Theory" in Coupland, N. and Jaworovski, A. (eds.), Sociolingusitics: A reader. Macmillan Education.

Goffman, E. (1963) Stigma: Notes on the management of spoiled identity. London: Penguin.

Gumperz, J. J. (ed.) (1982) Language and social identity. Cambridge University Press.

Janda, D. R. (1978) Hypercorrect-ion and Hyper-correction in Phonological Change, Edmonton: Linguistics Research.

Jones, E., Gallois, C., Barker, M. \& Callan, V. J. (1994) "Evaluations of interactions between students and academic staff: Influence of communication accommodation, ethnic group, and status", Journal of Language and Social Psychology, 13: 158-191.

Kovačević, B. (2004) „Stavovi prema varijetetima srpskog jezika”, Philologia 2, 33-38.

Kovačević, B. (2005) „Preuključivanje između standardnog oblika srpskog jezika i njegovih dijalekata i između ekavskog i ijekavskog izgovora", Zbornik Matice srpske za filologiju i lingvistiku 48(1-2): 283-297.

Labov, W. (1972) Sociolinguistic Patterns. Philadelphia: University of Pennsylvania Press.

Mey, J. L. (1985) Whose language?. Amsterdam/Philadelphia: Benjamins Paperbacks.

Miloradović, S. (2014) „Uzualni standard u urbanim centrima na kosovsko-resavskom I prizrensko-timočkom govornom području”, Zbornik Instituta za srpski jezik SANU II (Srpski jezik i aktuelna pitanja jezičke politike). Beograd: Institut za srpski jezik SANU: $143-150$.

Milroy, J. and Milroy, L. (1999) Authority in language. London/New York: Routledge.

Milroy, J. (2001) "Language ideologies and consequences of standardization", Journal of Sociolinguistics, 5(4): 530-555.

Novaković, A. (2016) „Hiperkorekcija u govoru učenika i studenata na području prizrensko-timočkog dijalekta”, Književnost i jezik, LXIII/3-4: 333-350.

Shepard, C., Giles, H., \& LePoire, B. (2001) "Communication accommodation theory" in W.P. Robinson \& H. Giles (Eds.), The new handbook of language and social psychology (pp. 33-56). Chichester, UK: Wiley.

Milroy, J. (2007)“The ideology of the standard language” in Llamas, C., Mullany L. \& Stockwell, P. (eds.), The Routledge Companion to Sociolinguistics. London - New York: Routledge, 133-139.

Paunović, T. (2008) "Globalization on the tip of my (mother) tongue" in Lopicic, V \& B. 
Misic Ilic (Eds.), Language, Literature, Globalization (Linguistics), 225-248.

Paunović, T. (2009),,Sociolingvistički pogled u susedovo dvorište: stavovi prema jezičkim Varijetetima", Radovi Filolozofskog fakulteta 11/1: 77-99.

Petrović, T. 2015. Srbija i njen jug: „Južnjački dijalekt”, između jezika, kulture i politike. Beograd: Fabrika knjiga.

Simard, L., Taylor, D. M., \& Giles, H. (1976) “Attribution processes and interpersonal accommodation in a bilingual setting”, Language and Speech, 19: 374-387.

Stanković, B., \& Stefanović, M. (2019) "Peeling the onion top-down: Language policy in Serbia between power and myth", Aegean Working Papers in Ethnographic Linguistics, 2(1), 17-41. doi:http://dx.doi.org/10.12681/awpel.20022

Swartz, D. (1997) Culture and power: the sociology of Pierre Bourdieu. Chicago \& London: University of Chicago Press.

Tajfel, H., \& Turner, J. C. (1986) "The social identity theory of intergroup behaviour" in S. Worchel \& W. G. Austin (eds.), Psychology of intergroup relations. Chicago, IL: Nelson-Hall, 7-24.

Trudgill, Peter (2003) A Glossary of Sociolinguistics. Oxford University Press.

\section{ТИПОВИ СТРАТЕГИЈА ГОВОРНИКА ЈУЖҢАЧКОГ ДИЈАЛЕКТА}

Сажетак: Фокус рада су стратегије говорникајужњачког дијалекта у свакодневној интеракцији (са акцентом на академско окружење). На основу података прикупљених дубинским интервјуима, представљена је могућа класификација говорника са југа (стандардна, нестандардна и еклектичка група). Повезивањем бурдијеовског теоријског оквира са кључним концептима теорије комуникативног прилагођавања (Communicative Accommodation Theory), предложене групе и њихове језичке стратегије су анализиране из интердисциплинарне перспективе. Поред аутентичног приступа проучавању и разумевању стигме на језичкој основи, као и односа моћи који се откривају у њој, допринос рада се огледа и у указивању на вредне смернице за будућа истраживања.

Кључне речи: јужњачки дијалекат, језичке стратегије, стигма 
